Imperial Ecology 



\title{
Imperial Ecology
}

\author{
Environmental Order in the \\ British Empire, 1895-1945
}

Peder Anker

Harvard University Press

Cambridge, Massachusetts, London, England 2001 


\section{To Nina}

Copyright (C) 2001, President and Fellows of Harvard College

All rights reserved

Printed in the United States of America

\section{Library of Congress Cataloging-in-Publication Data}

Anker, Peder.

Imperial ecology : environmental order in the British Empire, 1895-1945 / Peder Anker.

p. cm.

Includes bibliographical references (p. ).

ISBN 0-674-00595-3 (cloth : alk. paper)

1. Human ecology-Great Britain-History. 2. Natural resources-Great Britain-History. 3. Plant ecology—Great Britain-History. I. Title.

GF551 .A65 2001

304.2'09041-dc21 2001039407 